\title{
El lector
}

La poesía es para el hombre una de las formas de expresar su ser y se manifiesta por medio de la palabra, único instrumento que satisface sus exigencias. Todo lo que suele decirse a propósito de lo poético de algún paisaje o de algún fenómeno de la naturaleza señala solamente su utilidad en tanto que material poético, o alude a una muy lejana analogía, al modo animista, entre el poeta y la naturaleza. Lo mismo concierne a los actos o a los sentimientos del hombre que no se han realizado en la palabra. Pueden ser maravillosos, como la impresión que causa la poesía, pero nunca convertirse en ella, porque la poesía no encierra en sí misma, ni con mucho, todo lo bello a lo que el hombre tiene acceso. Ningún recurso de la fonética del verso es capaz de transmitir la verdadera voz del violín o de la flauta, no con acuerdo a ningún método estilístico puede encarnarse el brillo del sol o el soplo del viento.

La poesía y lá religión son las dos caras de una misma moneda. Ambas exigen del hombre trabajo espiritual. Pero no en nombre de una finalidad práctica, como la ética y la estética, sino en nombre de una finalidad más alta y desconocida, aun para ellas mismas. La ética adapta al hombre para la vida en sociedad, la estética busca aumentar su capacidad de deleitarse. La religión y la poesía guían al hombre en su renacimiento a una especie superior. La religión se dirige a la colectividad. Para sus fines - sean éstos la construcción de la Jerusalén celestial, la glorificación ininterrumpida de Alá, la purificación de la materia en el Nirvana - son necesarios los esfuerzos en conjunto, una especie de trabajo de pólipos que forman un arrecife de coral. La poesía siempre se dirige al individuo. Aun ahí donde el poeta habla con la multitud, habla por separado con cada uno de los integrantes de esa multitud. La poesía exige del individuo lo mismo que la religión exige de la colectividad. En primer lugar, el reconocimiento de su unicidad y su omnipotencia; en segundo, el perfeccionamiento de su Naturaleza. El poeta que ha comprendido "el confuso olor de la hierba", quiere que el lector sienta lo mismo, quiere que para todos "sea claro el libro astral" y que "todos puedan conversar con la ola del mar". Por eso el poeta, en los momentos de espíritu creador, debe poseer cierta 
sensación que hasta ese momento no hubiera sido meditada por nadie más, pero que sea de valor. Esto produce en él un sentimiento de catástrofe. Le parece que está diciendo sus últimas palabras, las más importantes, aquellas gracias a las cuales valió la pena que la tierra naciera. Este particular sentimiento, a veces va acompañado de un estremecimiento tal que le impediría incluso hablar, de no existir la sensación de triunfo que lo acompaña, la conciencia de haber creado combinaciones perfectas de palabras, semejantes a las que en alguna ocasión resucitaron a los muertos y destruyeron murallas enteras. También los malos poetas tienen estos dos sentimientos. El aprendizaje de la técnica los hace que aparezcan con menor frecuencia, pero que den mayores resultados.

La poesía siempre ha deseado desligarse de la prosa. Tanto en su aspecto tipográfico (antes caligráfico) pues comienza cada línea con mayúscula, como en el sonido, el ritmo que se escucha con claridad, la rima, la aliteración y el estilo, creando así una lengua "poética" especial (los trovadores, Ronsard, Lomonósov); también en su composición, al alcanzar una brevedad singular de pensamiento y en su aspecto eidético, es decir, en la selección de las imágenes. En todo esto la prosa siempre ha ido tras ella afirmando que no había propiamente ninguna diferencia entre ellas, como un pariente pobre que con su amistad asedia al rico. Ultimamente, sus esfuerzos parecieron tener éxito. Por un lado, bajo la pluma de Flaubert, Baudelaire y Rimbaud la prosa adquirió las maneras de una elegida del destino y, por el otro, la poesía, recordando que la búsqueda es una condición indispensable de su existencia, intenta incansablemente nuevos y nuevos medios de influencia acercándose a cotos vedados con el verso de Wordsworth, la composición de Byron, el verso libre y hasta el bosquejo, ya que Paul Fort publica sus poesías en renglones como los de la prosa.

Pienso que es imposible encontrar la línea divisoria exacta entre prosa y poesía, así como no la encontramos entre los vegetales y los minerales, los animales y los vegetales. Sin embargo, la existencia de modelos híbridos no degrada al tipo puro. $Y$ en lo referente a la poesía sus investigadores más recientes llegaron ya a un acuerdo. En Inglaterra sigue reinando el axioma de Coleridge, que define a la poesía como "las mejores palabras en el mejor orden". En Francia, la opinión de T. de Banville: "un poema es algo que ya ha sido creado y que no puede ser corregido". Y a estos dos puntos de vista se unió Mallarmé cuando 
dijo: "La poesía está en donde haya un esfuerzo exterior al estilo".

Expresándose con la palabra, el poeta siempre se dirige a alguien, a algún oyente. Con frecuencia tal oyente es él mismo, y aquí estamos hablando ya del desdoblamiento natural de la personalidad. Algunas veces es un cierto interlocutor místico, un amigo que aún no ha llegado a la amada; a veces es Dios, la Naturaleza, el Pueblo...

Esto, en el momento de la creación. Sin embargo, para nadie es un secreto - y menos que para nadie, para el poetaque cada poesía encuentra un lector vivo y real entre sus contemporáneos, a veces sus descendientes. Este lector, en modo alguno es digno del desprecio con que tan frecuentemente lo han tratado los poetas. Gracias a él los libros se publican, se crean reputaciones; él nos ha dado la posibilidad de leer a Homero, a Dante, a Shakespeare. Además, ningún poeta debe olvidar que él mismo, en relación con otros poetas, no es más que un lector. Sin embargo, todos nosotros somos semejantes al hombre que aprende una lengua extranjera con ayuda de manuales. Podemos hablar, pero no comprendemos cuando hablan con nosotros. Los manuales para los poetas son innumerables, pero no hay manuales para los lectores. La poesía se desarrolla y unas corrientes sustituyen a otras, pero el lector permanece el mismo y nadie trata de iluminar con la linterna del conocimiento los rincones de la oscura alma de lector. Ahora nos ocuparemos de esto.

Arites que nada, cada lector está profundamente convencido de que es una autoridad; éste porque ha ascendido hasta hacerse coronel, aquél porque ha escrito un libro sobre mineralogía, otro más porque sabe que aquí no hay ningún artificio: "si me gusta, es buena; si no me gusta, es mala; la poesía es la lengua de los dioses, ergo puedo juzgarla de modo absolutamente libre." Esa es la regla general, pero con su actitud posterior los lectores se dividen en tres tipos principales: el ingenuo, el snob y el exaltado.

El lector ingenuo busca en la poesía gratos recuerdos: si ama la naturaleza, condena a los poetas que no hablan de ella; si es un socialista, un Don Juan o un místico, busca poesías referentes a su especialidad. Quiere encontrar en los versos imágenes e ideas que le son habituales, menciones de las cosas que a él le gustan. Habla poco de sus impresiones y generalmente no motiva sus opiniones con nada. Suele ser bastante apacible, 
aunque está expuesto a ataques de ciega rabia, como todo hervíboro. Es común entre los críticos de la vieja escuela.

El snob se considera un lector culto; ama hablar del arte del poeta. Normalmente sabe de la existencia de alguna práctica de la técnica poética y la sigue a lo largo de la lectura del poema. De sus labios escuchamos que $x$ es un gran poeta porque introduce ritmos complejos, $y$ porque crea palabras nuevas, $z$ porque emociona mediante el camino de la repetición. Exprusa sus opiniones ampliamente y a veces hasta de un modo interesante, pero tomando en cuenta sólo una, y raras veces dos o tres de esas prácticas, inevitablemente se equivoca de la forma más lamentable. Se encuentra exclusivamente entre los críticos de la nueva escuela.

El lector exaltado ama la poesía y detesta la poética. En tiempos remotos podía encontrarse también en otras esferas del espíritu humano. Fue él quien exigió los autos de fe de los primeros médicos anatomistas que osaron descubrir el misterio de la creación divina. Se encontraba también entre los marineros que desaprobaron el primer barco de vapor, porque el navegante debe rezar a la virgen María para que el viento sea favorable y no quemar quién sabe qué leña para hacer girar quién sabe qué ruedas. De todos lados fue desplazado y se conservó únicamente entre los lectores de poesía. Habla del espíritu, el color y el sabor del poema, de su fuerza milagrosa o, por el contrario. de su marchitez, de la frialdad o de la calidez del poeta. Se encuentra con dificultad. (ha sido cada vez más desplazado por los primeros, tipos) y eso, entre los propios poetas.

El cuadro es desolador ¿no es cierto? Si consideramos la obra poética como la fecundación de un espíritu por otro a través de la palabra, (a semejanza de la fecundación natural) entonces esa idea nos recuerda el amor de los ángeles por las cainitas o, lo que es lo mismo, la cópula con un animal.

Sin embargo, puede haber un lector distinto, el lectoramigo. Este lector piensa únicamente en aquello que le dice el poeta, parece ser él quien escribió la poesía, la recuerda con su entonación, con su movimiento. El vive el momento de la creación en toda su complejidad y su vehemencia, sabe muy bien que la técnica une todos los logros del poeta y que sus virtudes son la prueba de que el poeta está marcado por la gracia de Dios. Para él una poesía es valiosa en todo su encanto material, como para el salmista son valiosos la saliva y el pubis cubierto de vello de su amada. A él no lo engañas con logros parciales, no te lo ganas 
por simpatía. Una excelente poesía irrumpe en su conciencia como algo indiscutible, lo transforma, define sus sentimientos y sus acciones. Sólo con la condición de su existencia la poesía cumple con su misión universal de ennoblecer a la especie humana. El lector así es real, yo conocí a uno. Y pienso que si no fuera por la terquedad humana y la negligencia, muchos podrían ser así.

Si yo fuera Bellamy, escribiría una novela acerca de la vida del lector venidero. Hablaría sobre las tendencias del lector y su lucha, sobre los enemigos lectores que desenmascaran la divinidad insuficiente de los poetas, sobre los lectores semejantes a la Gioconda de D'Annunzio, y los semejantes a Elena de Esparta, para la conquista de los cuales sería necesario superar a Homero. Afortunadamente no soy Bellamy, y de ese modo, habrá una mala novela menos.

Aquello a lo que el lector tiene derecho y por lo tanto debe exigir del poeta es el tema de este ensayo. Pero su finalidad no es enseñar a los poetas a escribir versos, como un manual de astronomía no puede enseñar a nadie a crear constelaciones. Sin embargo, puede servir a los poetas para la verificación de las cosas que ya tengan escritas y en el momento que antecede a la creación, les dará la posibilidad de considerar si el sentimiento está saturado, si la imagen ha madurado y la emoción es lo suficientemente intensa, o si es más conveniente limitar la voluntad y guardar las fuerzas para un mejor momento. No se debe escribir siempre que se pueda, sino siempre que se deba. La idea de cuando "se pueda" debe ser expulsada de todas las ramas de la investigación poética.

Delacroix dice: "Hay que estudiar incansablemente la técnica de nuestro arte para no pensar en ella en los momentos de la creación". Y en realidad, es necesario o bien no conocer nada de técnica o conocerla muy bien. Cuando Lérmontov tenía dieciséis años escribió "Angel", y sólo diez años más tarde pudo escribir otra poesía que pudiera comparársele. Pero "Angel" era una y todas los poesías de Lérmontov de los años 40 y 41 son maravillosas. Una poesía como "Palas Atenea" (que brota de la cabeza de Zeus) surge del espíritu del poeta y se convierte, por lo tanto, en un organismo independiente. Y como cualquier organismo vivo tiene su anatomía y su fisiología. Antes que nada vemos la combinación de las palabras, es decir la carne de la poesía. La naturaleza y la calidad de dicha combinación son objeto de estudio de la estilística. Después vemos que las diversas combi- 
naciones de palabras se complementan unas a otras y nos llevan a recibir una impresión determinada y percibimos entonces la osamenta de la poesía, es decir su composición. Por otro lado esclarécemos la naturaleza de la imagen, el sentimiento que impulsó al poeta al acto de la creación (el sistema nervioso de la poesía) y de este modo gozamos ya de lo eidético. Por último (aunque todo esto se lleva a cabo a un mismo tiempo) nuestra atención se ve atraída por el aspecto sonoro del poema (el ritmo, la rima, la combinación de vocales y consonantes) que, semejante a la sangre, vibra en sus venas y entonces comprendemos su fonética. Estas cualidades son, todas, inherentes a toda poesía, a la más genial y a la más diletante, tal como puede anatomizarse a un hombre vivo y a otro muerto. Pero los procesos fisiológicos en el organismo se realizan únicamente en caso de que haya cierta perfección y, tras haber hecho la autopsia de un poema, lo único que podemos decir es si hemos encontrado en el todo lo que debería haber y si lo hay en suficiente cantidad como para que pueda vivir.

Las leyes de su vida, es decir la interrelación de sus partes, deben ser estudiadas especialmente y el camino que a eso conduce prácticamente no ha sido abierto. 